\title{
Preparation and Properties of Organokaolin Natural Rubber Latex Base Vulcanisate
}

\author{
Ogbemudia Joseph Ogbebor ${ }^{1, ~ *}$, Felix Ebhodaghe Okieimen ${ }^{2}$, David Ehioghilen Ogbeifun², \\ Uzoma Ndubuisi Okwu ${ }^{1}$ \\ ${ }^{1}$ Research Support Services Department, Rubber \& Gum Tech. / Quality Control Division, Rubber Research Institute of Nigeria, Benin City, \\ Nigeria \\ ${ }^{2}$ Center for Biomaterials Research, University of Benin, Benin City, Nigeria
}

\section{Email address:}

ojo0001@yahoo.com (O. J. Ogbebor), fexokieimen@yahoo.com (F. E. Okieimen), daveogbe@yahoo.com (D. E. Ogbeifun), unokwu@yahoo.com (U. N. Okwu)

\section{To cite this article:}

Ogbemudia Joseph Ogbebor, Felix Ebhodaghe Okieimen, David Ehioghilen Ogbeifun, Uzoma Ndubuisi Okwu. Preparation and Properties of Organokaoli Nnatural Rubber Latex Base Vulcanisate. Advances in Materials. Vol. 4, No. 4, 2015, pp. 75-79.

doi: $10.11648 /$ j.am.20150404.11

\begin{abstract}
Natural rubber (NR) latex-organokaolin compounds have been investigated. The intercalated kaolin (100\% CECCTAB of clay) was used in aqueous rubber latex dispersion, from which a coagulum was obtained. The coagulum was used in natural rubber compounds and evaluated for its cure: scorch; $t_{s} 1$, optimum cure; $t_{90}$ min, minimum (ML) and maximum (MH) torque and mechano-physical properties viz: M100, M300, EB (\%), hardness and abrasion in mg/1000 rev. The scorch and optimum cure indicated a progressive drop with addition of organokaolin in natural rubber latex based compounds. Vulcanisate mechanical properties generally showed increase as organokaolin loading increased. A correlation between the measure of extent of vulcanization (MH-ML) and properties such as tensile strength, elongation at break, abrasion and hardness showed that the extent of crosslinking as a result of rubber-filler interaction of the natural rubber based compounds increased as organokaolin loading increased.
\end{abstract}

Keywords: Natural Rubber (NR), Hexadecyl trimethylammonium bromide (CTAB), Cation Exchange Capacity (CEC), Cure Properties, Vulcanisate Properties

\section{Introduction}

Clays are important raw materials, with estimated consumption of over 1,600, 000 tonnes consumed as fillers [1]. They have found uses in the polymer, paint, paper e.tc. industries as non-black fillers $[1,2]$. Clays are natural minerals comprising of certain groups of hydrous aluminum, magnesium and iron silicates that may contain sodium, calcium, potassium, and other ions. These silicates are called the clay minerals, the major clay mineral groups are kaolins, smectites, illites, chlorites and hormites. Kaolins are used to greatest extent (54\%) when compared to other non-black fillers. They are used as non-black fillers in polymers to cheapen and modify processing by reducing nerve in shaping operations and ensuring dimensional stability in unvulcanized stocks at high loadings $>40$ wt. \% [3]. Kaolins has also been used to aid smooth plastic surface, improve electrical resistance in wire and cable coatings and helps control flow properties in polishing compounds [4]. Recently, organomodified clays emerged as novel class of reinforcing fillers for the reinforcement of polymers. A unique feature of these materials is their ability to impart a rare combination of properties to the base polymer at low loadings $<10$ wt. $\%[4,5]$. This means that superior performance can be realized with significant weight savings. These composites are developed through either in situ polymerization, direct solution intercalation of the organically modified layered silicate or melting intercalation into the polymer matrix. A review of literature on organomodified filler-polymer composites show that montmorillonite (bentonite) has been studied extensively [5, 6 , $7,8,9,10,11,12,13]$. But as the natural deposits of montmorillonite minerals are rather limited and the demand for bentonites ever increasing, there has been considerable interest in finding substitute mineral. In this context, only scanty information is available with the relatively less expensive and abundantly available mineral like kaolin $[14,15]$. Kaolin 
consists chiefly of the mineral kaolinite and is abundantly available. Its low cost encourages its industrial utility. In the quest of developing organoclays from other layered clay resource aside bentonite, organoclay from kaolin (organokaolin) was prepared, investigated and applied as filler in NR compounds by us [16]. The NR was however in block form i.e. crumb rubber. It is known that aside solid rubber like crumb and sheet, other forms of natural rubber (NR) is latex. This has also been known as a suitable source for several rubber applications. Some advantages are ease of incorporation of additives like fillers suitably wetted out and dispersed in water and added to improve its properties [8] as aqueous dispersions or solutions. The absence of any risk of prevulcanization by heat also encourages the use of latex. Additionally, incorporation of chemicals (ingredients) in the latex stage, followed by further processing, definitely has the unique advantage of excellent dispersion and less molecular weight reduction [17]. There is however, scant information in literature on the use of organoclays in latex elastomers $[8,18$, 19]. The layered clay usually preferred has been montmorillonites. In this report, the effect of organokaolin on the processability of natural rubber latex base compounds, tensile mechanical properties and hardness of vulcanizate of the latex-base NR compounds is been reported.

\section{Main Body}

\subsection{Collection of Clay Samples}

Clay samples were collected from exposed faces of deposit situated on long. $06^{\circ} 39^{\prime} 05.3 \mathrm{E}$ and lat. $6^{\circ} 13^{\prime} 39.2^{\prime} \mathrm{N}$, purified by water washing through $75 \mu \mathrm{m}$ mesh size and its composition was $\mathrm{SiO}_{2}$ : 32.11\% wt., $\mathrm{Al}_{2} \mathrm{O}_{3}: 21.40 \%$, $\mathrm{TiO}_{2}: 4.30 \%, \mathrm{Fe}_{2} \mathrm{O}_{3}: 1.72 \%, \mathrm{~K}_{2} \mathrm{O}: 0.64 \%, \mathrm{MgO}: 6.48 \%, \mathrm{CaO}$ : $15.20 \%, \mathrm{Na}_{2} \mathrm{O}: 0.56 \%$. The $100 \%$ CEC of kaolin clay with hexadecyltrimethylammonium bromide (CTAB) was carried out using the procedure earlier reported in [16].

\subsection{Collection of Latex}

Natural rubber latex was collected from the clonal garden of Rubber Research Institute of Nigeria, bulked and sieved to remove dirt and debris before use in mix with the dispersed organokaolin in water.

Preparation of organokaolin filled natural rubber latexbase compounds.

$2,4,6$, and $8 \mathrm{phr}$ of modified clay were dispersed in $100 \mathrm{ml}$ of distilled water and stirred an ultrasonic stirrer (Oscar ultrasonics) for $30 \pm 5^{\circ} \mathrm{C}$ and aqueous suspension was obtained. This suspension was mixed with $850 \mathrm{ml}$ natural rubber latex (pre-determined to coagulate to $300 \mathrm{~g}$ dry natural rubber) and stirred vigorously (about $4 \mathrm{mins}$ ) with a standard steel stirrer until it mixed uniformly. Finally, the mixture was poured into a coagulating trough to auto-coagulate. The obtained coagulum was washed copiously with water and dried in an oven $\left(70^{\circ} \mathrm{C}\right)$ for 5 days until dry. This was then used for masterbatch preparation on a two roll mill (BanburyPullen, model, 35100). The mill opening was set at $1.4 \mathrm{~mm}$, and initial temperature of mill set at $80 \pm 5^{\circ} \mathrm{C}$. The mixing involved a two stage operations. In the first step an initial banding of natural rubber on the front roll of the two-roll mill, followed by $3 / 4$ cuts on both sides of the band, zinc oxide, stearic acid, paraffin oil and wax, allowed to mix properly for $5 \mathrm{~min}$. This was followed by the incorporation of the remaining ingredients and 6PPD for a further $3.5 \mathrm{~min}$ in the final step the addition of accelerator and vulcanizing agents (CBS and sulphur) for 2.0 min was done after the stock was allowed to cool to $70^{\circ} \mathrm{C}$ were incorporated to obtain natural rubber latex/organokaolin compounds as shown in table 2.0. The rheological behavior of the rubber compounds was determined on Alpha Oscillating Disc Rheometer (ODR 2000) using a $1^{\circ}$ rotor oscillating amplitude and frequency $50 \mathrm{~Hz}$ [20]. The cure rate index (CRI) and other parameters of cure were estimated from the obtained rheographs. Tensile specimens were cut from the moulded sheets, according to BS 903, Part A2 (DIN 53504) [21]. Tensile properties: M100, M200, M300, tensile strength and Elongation at break (\%) were determined at room temperature on Zwick/Roell testing machine Z005 with crosshead speed of $200 \mathrm{~mm} / \mathrm{min}$. The abrasion test was carried out in accordance to BS 903, Part A9, [22] consisting of a trial run, a running-in period and five test runs. Absolute value of abrasion was mean value from the five test runs expressed in milligrams per 1000 revolutions of the abrasive wheel. Hardness tests of the rubber vulcanizate were determined in accordance to BS 903 (ISO 7619), [23] with an international rubber hardness tester.

\section{Results and Discussion}

The rheological properties during cross-linking of the latex-base natural rubber filled with the clay ( $40 \mathrm{phr}), 2 \mathrm{phr}$, $4 \mathrm{phr}$, and $8 \mathrm{phr}$ organokaolin estimated from rheographs are shown in Table 4. It has been stated that ODR is a convenient technique for the functional evaluation of fillers for their reinforcing potentials $[24,25]$. The bulk clay 40phrfilled natural rubber latex exhibited the scorch $\left(\mathrm{t}_{\mathrm{s}} 2\right)$ of $1.3 \mathrm{~min}$, while the organophilized clay of $2 \mathrm{phr}$ indicated $2.1 \mathrm{mins}$, the $4 \mathrm{phr}$ organophilized clay was $1.56 \mathrm{mins}, 6 \mathrm{phr}$ was 1.53 mins and 8 phr was 0.06 mins indicating a progressive drop with addition of organokaolin, showing that the onset of cure is fastest in its presence. The optimum cure also showed a progressive drop with addition of organokaolin. This trend in cure behavior was earlier reported by Alex and Nah [8] in the study on organoclay-rubber nanocomposites via skim natural rubber; $\mathrm{Wu}$, et al [26] in the study of rubber-pristine clay nanocomposites prepared by co-coagulating rubber latex and clay suspension and that of Teh, et. al. [27] on natural rubber/organoclay nanocomposites compatibilized with epoxidized NR. However, the minimum torque (ML), which is measure of effective viscosity of unvulcanized mix, maximum torque $(\mathrm{MH})$, and the measure of the extent of vulcanization MH-ML, which indicates the extent of crosslinking as a result of rubber-filler interaction of the compounds were observed to increase as organokaolin filler loading increased. 
The mechanical properties of latex-based natural rubber bulk clay (40phr) and organokaolin filled compounds are shown in Table 3.0. This include tensile properties which include M100, M300 and tensile strength (TS) and elongation at break; There is observed improvement in the mechanical properties determined with increase in loading of organokaolin when compared to the $75 \mu \mathrm{m}$ bulk kaolin filled NR vulcanizate. While the bulk kaolin indicated $0.4 \mathrm{MPa}$ for the M100, the organokaolin indicated $0.7 \mathrm{MPa}$ at $2 \mathrm{phr}$, $0.8 \mathrm{MPa}$ at $4 \mathrm{phr}, 0.9 \mathrm{Mpa}$ at $6 \mathrm{phr}$ and $1.1 \mathrm{MPa}$ at $8 \mathrm{phr}$. In the same vein, M300 was $1.3 \mathrm{MPa}$ for bulk kaolin, organokaolin filled compounds were: $1.7 \mathrm{MPa}$ for $2 \mathrm{phr}, 1.8 \mathrm{MPa}$ for $4 \mathrm{phr}$, $1.9 \mathrm{Mpa}$ for $6 \mathrm{phr}$ and $2.1 \mathrm{MPa}$ for $8 \mathrm{phr}$. Tensile strength (TS) also indicated $10.8 \mathrm{MPa}$ for the $40 \mathrm{ph}$ bulk kaolin whereas, organokaolin was $16.7 \mathrm{MPa}$ for $2 \mathrm{phr}, 20.6 \mathrm{MPa}$ for $4 \mathrm{phr}$, $21.2 \mathrm{MPa}$ for $6 \mathrm{phr}$ and $23.1 \mathrm{MPa}$ for $8 \mathrm{phr}$. These improvements proves that more rubber molecules were exfoliated into the intercalated kaolin given rise to an intercalated kaolin (organokaolin) leading to a better dispersion of clay with formation of a more homogenous rubber-organokaolin network. This type of effect on vulcanizate properties of elastomer has also been reported by
Amarasiri, et. al. [22] on the work of natural rubber latexclay nanocomposite using montmorillonite clay as an alternative for conventional $\mathrm{CaCO}_{3}$. Conversely, the elongation at break reduced with increase of organokaolin in the latex-based NR vulcanizate. The abrasion also reduced with loading of the organokaolin. The hardness (IRHD) values were in agreement with the tensile properties. The extent of rubber-filler interaction (crosslinking indices), was correlated to tensile strength, elongation at break (\%), abrasion, and hardness as shown in Figure 1-4. These indicated that as the organokaolin filler presence increased so did the rubber-filler interactions enhanced in the latex based natural rubber compounds.

Table 1. Composition of fresh latex.

\begin{tabular}{ll}
\hline Constituents & $\mathbf{\%}$ \\
\hline Rubber hydrocarbon & 38 \\
Protein & 1.4 \\
Carbohydrates & 1.6 \\
Lipids & 2.2 \\
Inorganic constituents & 0.5 \\
Water & 58.5 \\
\hline
\end{tabular}

* Lipids include Glycolipids + phospholipids.

Table 2. Formulation for investigating organokaolin in latex-base natural rubber compounds.

\begin{tabular}{|c|c|c|c|c|c|}
\hline Compound Component & phr & phr & phr & phr & phr \\
\hline Sieved natural rubber & latex (mixed with & latex (mixed with & latex (mixed with & latex (mixed 6phr & latex (mixed 8phr \\
\hline latex & 40phr kaolin clay) & 2 phr organokaolin) & 4 phr organokaolin) & organokaolin) & organokaolin)) \\
\hline Paraffin oil & 10 & 10 & 10 & 10 & 10 \\
\hline Zinc oxide & 10 & 10 & 10 & 10 & 10 \\
\hline Stearic acid & 2 & 2 & 2 & 2 & 2 \\
\hline 6PPD & 1.5 & 1.5 & 1.5 & 1.5 & 1.5 \\
\hline Wax & 1.5 & 1.5 & 1.5 & 1.5 & 1.5 \\
\hline Sulphur & 2.8 & 2.8 & 2.8 & 2.8 & 2.8 \\
\hline
\end{tabular}

phr: parts hundred rubber,

6PPD: N-(1, 3-dimethylbutyl) - N'-phenyl-p-phenylenediamine,

CBS: N-cyclohexyl-2- benzothiazole sulfonamide,

Table 3. Cure characteristics $\left(150^{\circ} \mathrm{C}\right)$ of $100 \%$ CEC-organokaolin in latex-base natural rubber compounds.

\begin{tabular}{|c|c|c|c|c|c|}
\hline Properties & Bulk clay, phr & Organokaolin, phr & Organokaolin, phr & Organokaolin, phr & Organokaolin, phr \\
\hline Clay $75 \mu \mathrm{m}$ & 40 & 2 & 4 & 6 & 8 \\
\hline$t_{s 1}(\min )$ & 1.1 & 1.5 & 0.2 & 0.4 & 0.04 \\
\hline $\mathrm{t}_{\mathrm{s} 2}(\min )$ & 1.3 & 1.85 & 1.56 & 1.53 & 0.06 \\
\hline$t_{90}(\min )$ & 2.4 & 3.1 & 2.6 & 2.5 & 2.4 \\
\hline $\mathrm{T}_{\max }$ & 6.9 & 9.5 & 9.6 & 10.8 & 10.9 \\
\hline CRI & 125 & 100 & 100 & 103 & 98 \\
\hline ML (kgcm) & 3.4 & 6.39 & 7.95 & 8.3 & 8.51 \\
\hline
\end{tabular}

$\mathrm{T}_{\max }$ : Absolute torque level (T90+ML), ML: Torque minimum $(\mathrm{Kgcm}), \mathrm{MH}$ : Torque maximum $(\mathrm{kgcm}), \mathrm{CRI}$ : cure rate index, 100/( $\left.\mathrm{T}_{90}-\mathrm{T}_{\mathrm{s} 2}\right)$.

Table 4. Mechano-physical characteristics of 100\% CEC-organokaolin in natural rubber latex base compounds.

\begin{tabular}{|c|c|c|c|c|c|}
\hline properties & Bulk clay, phr & Organokaolin, phr & Organokaolin, phr & Organokaolin, phr & Organokaolin, phr \\
\hline & 40 & 2 & 4 & 6 & 8 \\
\hline M100 & 0.4 & 0.7 & 0.8 & 0.9 & 1.1 \\
\hline $\mathrm{M} 300, \mathrm{MPa}$ & 1.3 & 1.7 & 1.8 & 1.9 & 2.1 \\
\hline $\mathrm{TS}, \mathrm{MPa}$ & 10.8 & 16.7 & 20.6 & 21.2 & 23.1 \\
\hline $\mathrm{EB}, \%$ & 510 & 401 & 374 & 368 & 351 \\
\hline IRHD & 28 & 34 & 36 & 42 & 44 \\
\hline Abrasion, mg/1000 rev. & 0.22 & 0.35 & 0.75 & 0.82 & 0.91 \\
\hline
\end{tabular}




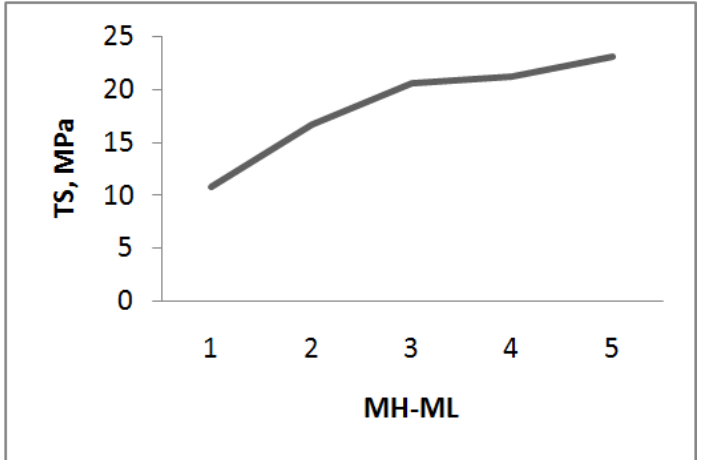

Fig. 1. Extent of rubber-filler interaction on tensile strength (TS) of latex base NR compounds.

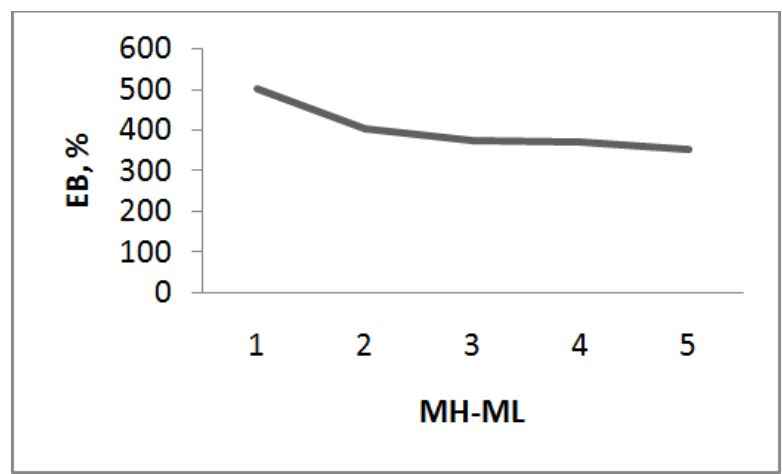

Fig. 2. Extent of rubber-filler interaction effect on elongation at break, \% of latex base NR compounds.

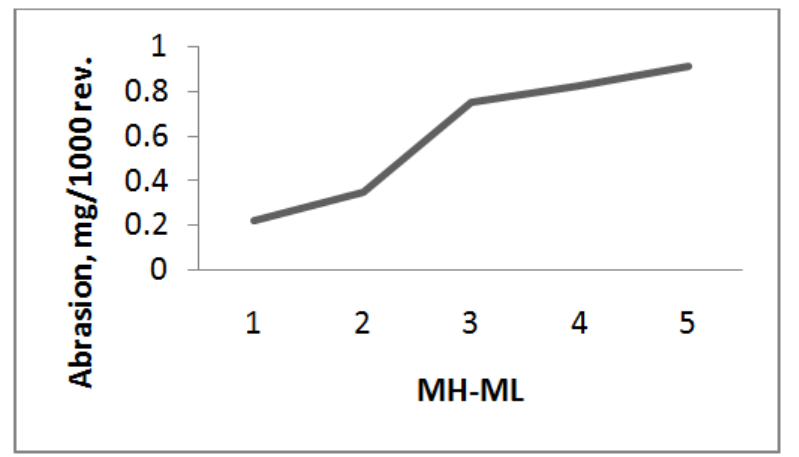

Fig. 3. Extent of rubber-filler interaction effect on abrasion $\mathrm{mg} / 1000 \mathrm{rev}$. of latex base NR compounds.

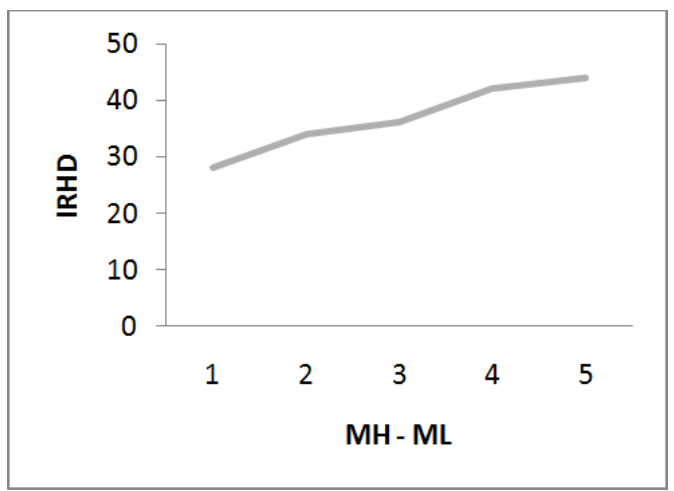

Fig. 4. Extent of rubber-filler interaction effect on IRHD of latex base NR compounds.

\section{References}

[1] Murray H.H., (2006). Current industrial applications of clays. Clay Sci. 12: 106-112

[2] Murray H.H., In E. Dominguez, G. Mas and F. Gravers Eds., A Clay Odessey, Elsevier, 2003, pp. 3-10.

[3] McCrum N.G., Buckley C.P., and Bucknall C.B., Principles of Polymer Engineering, Oxford Univ. Press, New York, (2010), p. 283.

[4] Murray H.H. and Kogel J.E. (2005). Engineered clay products for the paper industry, J. Appl. Clay. Sci. 29: 199-206.

[5] Kulshreshtha A.K, Maiti A.K., Choudhary M.S, Rao, K.V (2006). Nano-addition of raw bentonite enhances polypropylene (PP) properties. .J. Appl. Polym. Sci. 99, 10041009.

[6] Zidelkheir B, Abdelgoad M. (2008). Effect of surfactant agent upon the structure of montmorillonite. J. Therm. Anal., Calorim. 94: 181-187

[7] Bakshi M.S., Sood, R. (2004). Cationic surfactant-poly(amido amine) dendrimer interactions studied by krafft temperature measurements.Physiochem.Eng. Aspects. 233: 203-210.

[8] Alex, R., Nah C., (2006). Preparation and characterization of organoclay-rubber nanocomposites via a new route with skim natural rubber latex. J. Appl. Polym. Sci. 102: $3277-$ 3285 .

[9] Yang H, Zheng X, Huang W, Wu K, (2008). Modification of montmorillonite with cationic surfactant and application in electrochemical determination. Coll. \& surf. B: Biointerfaces 65: 281-284

[10] Zhou L, Chen H, Jiang X, Lu F, Zhou Y, Yin W, Ji X, (2009). Modification of montmorillonite surfaces using a novel class of cationic Gemini surfactants. J. coll. \& inter. Sci. 332: 16-21.

[11] López-Manchado M A, Arroyo M, Herrero B. (2003).Organomontmorrillonite as substitute of carbon black in natural rubber compounds. Polymer 44:2447-2453

[12] Paul DR, Zeng QH, Yu AB, Lu GQ. (2005).The interlayer swelling and molecular packing in organoclays .J. Colloid. \& Interface. Sci. 292: 462-468.

[13] Ahmadi S.J, G'sell C,Huang Y, Ren N, Mohaddespour A, Hiver J. (2009). Mechanical properties of NBR/clay nanocomposites by using a novel testing system. Comp. Sci. Technol. 60: 2566-2572.

[14] Sukumar R, Menon ARR. (2007).Organomodified kaolin as reinforcing filler for natural rubber. J. Appl. Polym. Sci. 107: 3476-3483.

[15] Yahaya LE, Adebowale KO, Menon ARR, Olu-Owolabi BI.(2012). Natural rubber/organoclay nanocomposite from tea (Camellia Sinensis) seed oil derivative. Am. J. Mat. Sci. 2: 1-5.

[16] Ogbebor OJ, Okieimen FE, Okwu UN \& Ogbeifun DE. (2015). Organomodified kaolin as filler for natural rubber. Chem. Ind. Chem. Eng. Quart. : doi/1451-9372/2015 
[17] Vanderbilt RT (1990). The Vanderbilt Latex Handbook, $3^{\text {rd }}$ Ed., R. T. Vanderbilt Co., Inc., Norwalk, CT. pp.

[18] Amarasiri A, Ratnayake UN, De Silva UK, Walpalage S and Siriwardene S. (2013). Natural rubber latex-clay nanocomposite: use of montmorillonite clay as an alternative for conventional $\mathrm{CaCO}_{3}$. J. Natn. Sci. 41 (4): 293-302.

[19] Jacob A, Kurian P, \& Aprem AS. (2008). Transport properties of natural rubber latex layered clay nanocomposites. J. Appl. Polym. Sci., 108 4: 2623-2629.

[20] ISO 3417 (2000-E) Rubber - Measurement of Vulcanisation Characteristics Disc Rheometer.

[21] British Standards Institute, BS 903; Part A2: Determination of Tensile Stress-Strain Properties, (DIN 53504).

[22] British Standards Institute, BS 903; Part A9: Determination of Abrasion Resistance.
[23] British Standards Institute, BS 903, Part A57: Determination of Hardness, (ISO 7619).

[24] Morton, M. (Ed)., Rubber Technology, Van Nostrand Reinhold, New York, 2005, pp. 100-120.

[25] Iyasele JU, Okieimen FE, (2008). Rheological properties and state of cure of natural rubber compounded with blend of carbonized melon seed shell and carbon black J. Chem. Soc. Nig. 33: 162-165.

[26] Wu Y.P., Wang Y.Q., Zang H.F., Yu D.S., Zhang L.Q., \& Yang J. (2005). Rubber-pristine clay nanocomposites prepared by co-coagulating rubber latex and clay aqueous suspension. Comps. Sci. and Tech. 65 (7-8): 1195-1202.

[27] Teh PL, MohdIshak ZA, Hashim AS, Karger-Kocsis J, Ishiaku US. (2006). Physical properties of natural rubber/organoclay nanocomposites compatibilized with epoxidized natural rubber J. Appl. Polym. Sci., 100: 1083-1088. 